\title{
KRISIS MORALITAS PADA REMAJA DI TENGAH PANDEMI COVID-19
}

Penulis
Institusi
Email Korespondensi
DOI

Kata Kunci:

Krisis Moralitas

Remaja

Globalisasi

Keywords:

Morality Crisis

Teenager

Globalization

\author{
Muhammad Rafi Athallah Mewar \\ Fakultas Ilmu Sosial dan Ilmu Politik, Universitas Muhammadiyah Jakarta \\ athallahrafi0@gmail.com
}

10.53947/perspekt.v1i2.47

\begin{abstract}
Abstrak
Selain ekonomi dan kesehatan, dampak lain dari pandemi COVID19 ini juga berdampak kepada moralitas seseorang khususnya para remaja di Indonesia ini. Pentingnya pendidikan moral di masa pandemi ini khusus para remaja memang sangat diperlukan. Pasalnya jika hal tersebut tidak bisa cepat diselesaikan, maka dampak dari krisis moralitas akan menjadi panjang. Krisis moral yang tengah terjadi di Indonesia ini cukup banyak, misalnya anak muda kita sudah mulai menghilangkan budaya berkata "tolong", "maaf", dan "terima kasih". Ketiga hal tersebut merupakan hal dasar dalam beretika, dan kini hal dasar dalam beretika saja mereka tidak gunakan dalam kehidupan sehari-hari. Hal tersebut terjadi karena para remaja Indonesia kurang melakukan literasi dan menyaring budaya luar yang masuk ke dalam negeri kita. Dengan melakukan pendidikan karakter kepada mereka dan membantu mereka untuk memperbaiki moralitas mereka, maka krisis moralitas yang tengah terjadi bisa perlahan diperbaiki dan dampak baik tersebut akan berpengaruh besar terhadap generasi anak muda yang akan datang.
\end{abstract}

\begin{abstract}
In addition to the economy and health, other impacts of the COVID19 virus pandemic also have an impact on one's morality, especially teenagers in Indonesia. The importance of moral education in this pandemic period, especially for teenagers, is really needed. The reason is that if this cannot be resolved quickly, the impact of the morality crisis will be long. There are many moral crises currently happening in Indonesia, for example, our young people have started to eliminate the culture of saying "please", "sorry", and "thank you". These three things are basic things in ethics, and now they don't use the basic things in ethics in everyday life. This happens because Indonesian youth lack literacy and filter out foreign cultures that enter our country. By conducting character education for them and helping them to improve their morality, the current moral crisis can be slowly remedied and this good impact will have a major impact on the next generation of young people.
\end{abstract}

\section{PENDAHULUAN}

Wabah COVID-19 yang tengah menjadi pandemi di seluruh dunia ini sangat mempengaruhi sikap dari manusia itu sendiri. Kemudian COVID-19 telah mempengaruhi dari segala sisi aspek kehidupan manusia.
Aspek-aspek tersebut yaitu aspek sosial, aspek politik, aspek budaya, dan aspek ekonomi (Nurohmah \& Dewi, 2021). Bahkan COVID-19 sangat berpengaruh terhadap sistem pendidikan kita. Pemberlakuan belajar secara tatap muka untuk sementara 
ditiadakan dan digantikan melalui metode daring (online). Setiap peserta didik mengikuti pembelajaran melalui media online seperti video conference, Google Classroom, e-learning, dan metode lainnya. Akan tetapi jika dilihat sekarang ini, metode tersebut justru perlahan merusak moralitas dari para anak muda tersebut. Pasalnya para remaja yang kelak akan menjadi calon penerus generasi bangsa selanjutnya harus memiliki kaidah moralitas yang baik. Pentingnya pendidikan moralitas untuk para remaja ini memang sangat penting.

Dalam keluarga, orang tua memang menjadi media primer dalam media sosialisasi terhadap anaknya. Orang tua adalah guru sekaligus kepala sekolah bagi anak-anaknya (Purwandari dkk., 2021). Akan tetapi kini sudah kurang efektif karena adanya dampak globalisasi. Para orang tua hanya menuntun anaknya untuk selalu melakukan kebaikan. Disisi lain para remaja juga tidak hanya menerima sosialisasi hanya dari orang tua saja. Lingkungan bermain dan lingkungan pendidikan juga berpengaruh terhadap sikap remaja tersebut. Efek perkembangan globalisasi juga sangat berdampak terhadap sikap para remaja di tengah pandemi ini. Memang sudah tak bisa dipungkiri kembali bahwa salah satu perkembangan globalisasi yang paling berpengaruh adalah perkembangan teknologinya yaitu internet. Fenomena merosotnya moral pada remaja \& peserta didik tersebut merupakan salah satu akses dari kondisi masyarakat yang sedang berada dalam fase transformasi sosial menghadapi era sosial (Tilaar, 1998). Melalui internet, kita bisa melihat dan mencari sesuatu dengan sangat bebas. Sangat sekali dampak positif yang diberikan oleh internet, akan tetapi dampak negatifnya juga terkesan cukup banyak. Kini para remaja dapat dengan mudahnya mencari sesuatu melalui situs yang sudah disiapkan oleh internet. Secara tidak langsung hal tersebut juga mempengaruhi moralitas dari para remaja tersebut. Orang tua sudah tidak menjadi panutan dan tauladan utama dari para remaja karena adanya internet dan penggunaan internet yang berlebih.

Semasa pandemi ini masih berlangsung, maka masalah yang diatasi juga akan banyak dan untuk mengatasi problematika diatas, maka diperlukan untuk melakukan penguatan dan penanaman nilainilai kaidah moralitas dalam diri para remaja untuk membangun dan menumbuhkan sikap positif dalam dirinya. Hal tersebut guna untuk menyelesaikan segala permasalahan yang berkaitan dengan kaidah moralitas dalam diri para remaja. Karena pada dasarnya moral dan karakter merupakan suatu pembelajaran yang membahas aspek nilai dan perilaku seorang manusia yang berkaitan dengan nilai keTuhanan, diri manusia itu sendiri, kepada masyarakat, dan lingkungan yang bisa diwujudkan dalam suatu bentuk pemikiran, perkataan, perbuatan dan sikap, dan perasaan yang berdasarkan norma-norma dan nilai yang berlaku. Oleh sebab itu mengapa penitngnya menananmkan kaidah-kaidah dasar moralitas kepada para remaja gerenrasi sekarang. Guna untuk memperbaiki pola berpikir para remaja dan menerapkan nilai moral dan membuat karakter para remaja Indonesia menjadi lebih baik. 


\section{KAJIAN LITERATUR}

\section{Pengertian Moralitas Dan Krisis Dari Moralitas}

Berdasarkan Kamus Bahasa Indonesia (KBBI) nilai adalah harga, yang berguna dalam diri manusia. Sedangkan menurut I Wayan Koyan, nilai merupakan segala sesuatu yang berharga. Ia juga berpendapat, bahwa nilai itu dibagi menjadi dua yaitu nilai aktual dan nilai ideal (Koyan, 2000). Kata moral diambil dari bahasa Latin yaitu, mos (jamak, mores) yang berartikan kebiasaan atau adat. Sedangkan moralitas secara lughawi juga berasal dari bahasa Latin mos yang artinya sama dengan moral yaitu kebiasaan atau adat istiadat. Moralitas adalah sifat moral atau keseluruhan asa dan nilai yang berkenaan dengan baik dan buruk. Jadi, moralitas merupakan suatu perbuatan yang artinya segi moral suatu perbuatan atau baik buruknya perbuatan tersebut.menurut Hurlock definisi moral adalah perilaku yang sesuai dengan kode kelompok sosial. Moral itu sendiri berarti tata cara, kebiasaan, dan adat. Perilaku moral dikendalikan oleh konsep-konsep moral atau peraturan perilaku yang telah menjadi kebiasaan bagi anggota suatu budaya yang ada (Hurlock, 2011).

Dengan demikian, pengertian dari moral tersebut dapat dipahami dengan mengklasifiksikannya sebagai berikut:

a) Moral sebagai ajaran kesusilaan, berarti segala sesuatu yang berhubungan dengan tuntutan untuk melakukan perbuatan-perbuatan baik dan meninggalkan perbuatan buruk yang bertentangan dengan ketentuan yang sudah berlaku di dalam suatu lingkungan masyarakat

b) Moral sebagai aturan, berarti ketentuan yang digunakan oleh masyarakat untuk menilai suatu perbuatan manusia, apakah dirinya sudah termasuk kedalam baik atau buruk.

c) Moral sebagai gejala kejiwaan yang timbul dalam bentuk perbuatan atau sikap, seperti berani, jujur, sabar, gairah, dan lain sebagainya.

Di tengah pandemi COVID-19 yang tengah kita bersama hadapi, tentu saja berpengaruh dengan sikap dan perilaku di lingkungan masyarakat. Karena pada dasarnya setiap manusia pasti mengalami sebuah perubahan atau perkembangan, baik itu perubahan yang bersifat nyata atau yang menyangkut dengan perubahan fisik, kemudian maupun perubahan yang bersifat abstrak atau perubahan yang secara langsung berhubungan dengan aspek psikologisnya.

Krisis moralitas itu sendiri merupakan pudarnya sikap, karakter, dan perilaku yang berhubungan dengan kebaikan dari seseorang. Pada dasarnya karakter merupakan suatu implementasi dari tingkah laku dan sikap seseorang, dimana sikap dan karakter tersebut merupakan salah satu pilar penting yang menentukan jalan hidupnya seseorang tersebut. Kemudian agen sosialisasi juga mendapatkan peran penting dari terbentuknya karakter atau perilaku pada seseorang. Keluarga menjadi pilar pertama dalam pengaruhnya moralitas di diri seseorang, sisanya tergantung dari orang tersebut dengan memilih agen sosialisasi sekundernya. Jika tidak ada keseimbangan antara keluarga sebagai agen sosialisasi primer dengan lingkungan sosial sebagai agen sosialisasi sekunder, maka besar kemungkinan seseorang tersebut akan mengalami suatu krisis moralitas. 


\section{METODE PENELITIAN}

Metode yang digunakan dalam penelitian artikel ini, menggunakan metode penelitian kualitatif dengan studi literatur. Peneliti mengambil beberapa informasi dari banyak penelitian yang sudah dilakukan sebelumnya. Hal tersebut guna sebagai sebuah perbandingan, baik itu sebuah kekurangan atau kelebihan yang sudah ada di dalam penelitian sebelumnya. Penelitian ini dilakukan guna menelaah kasus penurunannya moralitas dalam diri remaja di Indonesia, kasus-kasus penurunan moral, dan cara menanggulanginya. Memang sudah tak bisa di pungkiri kembali,krisis moralitas yang sudah marak terjadi ditabah dengan adanya pandemi COVID-19 yang semakin memperkeruh suasana yang tengah terjadi. Karena itu dengan mendasarnya artikel yang dibuat ini, dengan membandingkan kasuskasus penurunan moralitas yang terjadi para remaja saat ini dari berbagai sumber artikel maupun berita guna menyelesaikan berbagai permasalahan moralitas di Indonesia dengan cara menanamkan nilai-nilai dan menjalankan kaidah moralitas kepada para remaja di Indonesia.

\section{HASIL DAN PEMBAHASAN}

\section{Kaitan Remaja Dengan Meningkatnya Kasus Krisis Moralitas}

Pada hakekatnya, manusia tidak akan bisa lepas dari kehidupa bersosial karena selain sebagai makhluk individu mansuia juga adalah makhluk sosial. Kuypers menguraikan bahwa manusia sebagai makhluk sosial berarti manusia dituntut untuk senatiasa melakukan hubungan sosial dengan manusia atau individu lain dalam hidupnya, sejak manusia membentuk pribadinya, sampai ia kemudian meninggal dunia, dimanapun individu/manusia itu berada. Hal ini yang menyebabkan manusia sebagai makhluk sosial tidak dapat hidup sendiri di tengah-tengah bergaulan manusia lainnya (Santoso, S. A., \& Chotibuddin, 2020). Pada dasarnya hubungan sosial yang tertuang dalam ajaran-ajaran teologi yang berdasarkan pada moral yang biasa disebut dengan teologi moral.

Fenomena COVID-19 ini berdampak pada moral/karakter dan hubungan sosial yang terjadi di tengah lingkungan masyarakat semenjak diberlakukannya Pembatasan Sosial Berskala Besar (PSBB) dan Pemberlakuan Pembatasan Kegiatan Masyarakat (PPKM) di tengah pandemi ini. Krisis moralitas dan krisis sosial bukan hanya terjadi pada orang yang lebih tua saja, akan tetapi juga melanda kepada anak muda atau remaja. Krisis moralitas yang tengah melanda kaum remaja di Indonesia ini sudah dibilang cukup kritis. Orang tua bukan lagi menjadi agen sosialisasi primer, dikarenakan kini para anak remaja bisa memilih siapa panutan yang ingin ia contoh. Namun, yang jarang kita ketahui bahwa kita tidak siapa yang dipanuti oleh para remaja tersebut, dan hasilnya kini para remaja justru mengalami krisis moralitas dalam dirinya. Banyak sekali kasus-kasus yang bisa dikaitkan dengan remaja yang mengalami keterbelakangan moralitasnya.

Hal ini bisa berkaitan karena dalam belakangan ini banyak sekali kasus-kasus pelanggaran norma oleh para remaja. Contohnya banyak kasus pembegalan oleh gangster yang di dominasi oleh anak muda, 
banyak kasus kekerasan seksual yang dilakukan oleh para remaja, dan hilangnya sikap hormat atau rendah hati kepada orang yang lebih tua. Tentu dampak tersebut sangat berpengaruh terhadap remaja lainnya yang pada akhirnya mengikuti jejak remaja lain. Memang kondisi seseorang di masa remaja masih bisa dikatakan belum mempunyai arah. Mengapa bisa belum mempunyai arah? Karena menurut psikologi seseorang yang sudah digolongkan sebagai remaja sedang berada di fase pembentukan karakter asli dari mereka. Faktor tersebutlah mengapa para remaja banyak sekali melakukan sebuah tindakan yang melawan norma dan menyebabkan terjadinya krisis moralitas. Lalu apa saja faktor-faktor penyebab dari rusaknya moral pada remaja pada saat ini? Berikut adalah pemaparan tentang faktorfaktor penyebab terjadinya kerusakan moral pada remaja:

a) Kemajuan teknologi

b) Memudarnya kualitas keimanan

c) Pengaruh lingkungan

d) Hilangnya rasa tanggung jawab (kejujuran, rendahnya sikap disiplin, dll.)

e) Tidak memikirkan dampak jangka jauh terhadap sikap yang dilakukannya pada saat muda.

f) Dan lain sebagainya.

Ditambah lagi dengan masalah pandemi virus COVID-19 ini, kelakuan remaja yang mengalami krisis moralitas semakin susah untuk dikendalikan. Kini yang baru terjadi adalah saat pelaksanaan Masa Orientasi Siswa (MOS) pada suatu sekolah berjalan tidak lancar karena adanya beberapa murid yang mengucapkan kata-kata yang kurang pantas untuk dikatakan dan tidak menghormati para panitia acara. Di masa pandemi ini memang kita sangat mengandalkan teknologi internet dalam menjalani semua aktivitas karena hal tersebut juga anjuran yang disampaikan oleh pemerintah. Karena kasus tersebut, semakin terlihat buruknya beberapa sikap remaja di masa pandemi ini.

Kemajuan IPTEK saat ini justru menjadi bumerang dan bahkan berbanding terbalik dengan moralitas yang dimiliki oleh para remaja yang semakin terdegradasi seiring dengan perkembangan zaman. Kasuskasus diatas sudah sampai tahap yang memprihatinkan. Dengan adanya kemajuan IPTEK banyak sekali kebaikan dan manfaat berkat adanya kemajuan IPTEK yang dapat dipelajari. Namun memang kurangnya literasi dan bimbingan kepada para remaja yang mengakibatkan dampak negatif dari kemajuan teknologi. Menurut penelitian yang dilakukan oleh Thomas Lickona (pendidik karakter dari Cortland University), sebuah bangsa yang sedang menuju jurang kehancuran, jika memiliki sepuluh tandatanda, yaitu; 1) meningkatnya kekerasan di kalangan remaja, 2) membudayakan sikap ketidakjujuran, 3) sikap fanatik terhadap suatu kelompok, 4) rendahnya rasa hormat kepada orang yang lebih tua dan guru, 5) semakin kaburnya moral baik dan buruk, 6) penggunaan bahasa yang buruk, 7) meningkatnya perilaku merusak diri, seperti menggunakan narkoba, mengkonsumsi alcohol, dan seks bebas, 8) rendahnya rasa tanggung jawab sebagai individu dan sebagai warga Negara, 9) menurunya etos kerja, 10) adanya rasa saling curiga dan kekurangan rasa kepedulian terhadap sesama (Lickona \& Wamaungo, 2013). 
Bisa disadari bahwa moral/karakter pada manusia bersifat fleksibel (yang dimaksud dapat diubah atau dibentuk). Moralitas di dalam diri manusia itu sendiri suatu saat bisa baik dan pada saat yang lain bisa menjadi jahat. Hal tersebutlah yang dimaksud mengapa karakter/moral pada manusia itu bersifat fleksibel. Perubahan karakter/moral ini bisa terjadi tergantung pada bagaimana proses interaksi antara potensi dan sifat alami yang dimiliki manusia dengan mengkondisikan lingkungan mereka, budaya, pendidikan, demografis, dan alam. Hal ini sangat berpengaruh terhadap pembentukan karakter/moral dalam diri manusia terutama para remaja, yang notabenenya masih dalam pembentukan dan memilih karakter. Kebanyakan saat ini para remaja kesulitan akan memilih karakter/moral. Karena remaja yang pada akhirnya salah dalam memilih karakternya yang menyebabkan terjadinya krisis moralitas yang kini banyak dilanda oleh para remaja.

Media sosial yang kini juga sangat berpengaruh dengan mental para remaja. Pandemi COVID-19 membuat kehidupan bersosialisasi para remaja menjadi terhambat, dikarenakan pemerintah melarang kepada masyarakat untuk membuat kerumunan karena takut terjadi penyebaran virus di kerumunan tersebut. Banyak sekali kerusakan moral atau karakter pada remaja yang terjadi di media sosial. Komentarkomentar yang negatif dengan maksud candaan dan tidak melihat konteks dari suatu konten di media sosial tersebut secara tidak langsung justru membuat sebuah keributan. Dampak dari krisis moralitas yang disebabkan media sosial salah satunya adalah membuat kini banyak orang khususnya remaja menjadi antisosial terhadap lingkungannya. Antisosial merupakan sebuah sikap apatis terhadap lingkungan sekitarnya dan hanya peduli dengan dirinya sendiri entah itu demi menjaga keamanan dirinya atau untuk sebuah hiburan.

Contohnya banyak sekali orang yang melakukan konten prank yang di upload melalui platform media sosial. Konten prank yang awalnya dilakukan karena untuk melakukan hiburan dan dengan pengkonsepan yang jelas, kini banyak di lencengkan oleh kebanyakan para remaja. Mereka melakukan prank tanpa memikirkan dampaknya terhadap orang disekitarnya. Seperti pada kasus Ferdian Paleka yang membuat konten prank dengan memberikan sumbangan yang berisikan sampah. Yang menjadi permasalahan karena target prank dari mereka adalah orang yang benar-benar membutuhkan bantuan karena mengalami kesulitan di tengah pandemi ini. Memang kasus ini sudah dibawa ke pihak berwajib, akan tetapi hal yang dilakukan oleh Ferdian Paleka banyak sekali di contoh oleh para remaja lainnya. Yang pada akhirnya banyak sekali kasus prank yang menjadi cermin terjadinya krisis moralitas pada remaja. Selain mengatas namakan "candaan" dan "konten" para remaja tersebut justru tidak merasa bersalah atas perilaku yang mereka lakukan. Jadi dampak krisis moralitas pada suatu remaja juga bersifat menular kepada remaja lainnya, karena kini para remaja kekurangan akan panutan yang ingin mereka contoh guna membimbing pembentukan karakter pada dirinya. 
Pentingnya Mengaplikasikan NilaiNilai Kaidah Moralitas Kepada Remaja Dalam Kehidupan Sehari-Hari Di Tengah Pandemi Covid-19

Semenjak masuknya COVID-19 keIndonesia dan menjadi sebuah fenomena pandemi, banyak sekali perubahan yang dialami dan dirasakan oleh masyarakat Indonesia. Perlahan-lahan terjadi sebuah perubahan budaya yang secara tidak langsung mempengaruhi masyarakat semenjak pandemi ini berjalan. Salah satunya adalah dalam dunia pendidikan. Berlakunya peraturan yang dikeluarkan oleh Menteri Pendidikan dan Kebudayaan Indonesia No. 4 Tahun 2020 yang membahas tentang pembelajaran jarak jauh, guna mencegah penyebaran virus COVID-19 yang tengah melanda Indonesia (Kemdikbud, 2020). Saat ini para pendidik dan juga peserta didik menjalankan kebijakan itu dengan melakukan proses pembelajaran secara daring. Kemudian pada masa pandemi ini juga, pemerintah menerapkan kebijakan yaitu Social Distancing bagi seluruh masyarakat yang mengharuskan untuk mengurangi segala kegiatan di luar rumah dan beberapa pekerjaan yang bisa dilakukan dirumah juga diberlakukan WFH (Work from Home). Menurut Galuh Purwandari dkk pendidikan dilakukan sebagai suatu proses pembudayaan dan pemberdayaan pada peserta didik yang berlangsung sepanjang hayat, walaupun pada masa pandemi seperti ini, pendidikan harus tetap berjalan. Pendidikan tidak hanya sekedar penyampianmaterisaja namun juga penanaman pendidikan mengenai keagamaan, seperti halnya umat musilm, wajib melaksanakan sholat, dan mengaji (Purwandari dkk., 2021).
Akan tetapi pengaruh pandemi ini terhadap para remaja yaitu menurunnya nilai moralitas atau pembentukan karakter dalam diri para remaja. Sebenarnya sudah sejak lama Indonesia mengalami krisis moralitas khususnya bagi para remaja, tetapi kondisinya justru bertambah buruk ditambah lagi dengan pandemi COVID-19 yang kini masih menjadi problematika utama yang ingin segera diselesaikan. Tentu saja hal ini menjadi peran penting dari orang tua dan tenaga pendidik yang harus saling bekerja sama dan berkontribusi di tengah pandemi ini dalam membentuk karakter serta moral para remaja agar sesuai dengan nilai dan norma yang berlaku. Dengan catatan saat ini adalah sistem pendidikan yang kini diterapkan oleh bangsa kita. Karena pada dasarnya seberapa kerasnya kita mengajarkan sebuah nilai-nilai moralitas serta norma kepada para remaja, hal ini tidak menjamin untuk membentuk karakteristik serta pola pikir sesuai yang diharapkan.

Pendidikan karakter membutuhkan sebuah proses yang lama-kelamaan menjadi sebuah kebiasaan. Pembiasaan dalam berbuat baik, jujur, berani, dan sifat baik lainnya serta malu bila melakukan sebuah sifat yang buruk. Menimbulkan rasa malu dapat secara tidak langsung berpengaruh terhadap alam bawah sadar para remaja sehingga mereka menghindari dari sifat buruk tersebut. Pembentukan karakter tidak dapat terbentuk secara instan, namun membutuhkan proses dan harus dilatih secara serius dan proporsional agar mencapai hasil yang ideal.

Dalam agama Islam, pendidikan karakter bersumber dari Al-Quran dan AsSunnah. Karakter atau akhlak dalam Islam ini 
terbentuk atas dasar prinsip ketaatan, kepasrahan, dan kedamaian yang sesuai dengan makna dari dasar kata Islam itu sendiri. Ajaran dalam Islam tentang pendidikan karakter bukan hanya sekedar teori semata, tetapi juga para figur Nabi Muhammad saw tampil sebagai suri tauladan. Kemendikbud dalam penguatan pengelolaan karakter juga menjelaskan bahwa pendidikan karakter itu mencakup beberapa dimensi, yaitu dimensi olah hati (etik), pola pikir (literasi), olah rasa (estetik) dan olahraga (kinestetik).

Indonesia pada tahun 2020 hingga di masa yang akan datang akan ditentukan oleh generasi muda sebagai penerus bangsa. Permasalahan moral yang melanda para remaja dan anak muda lainnya kini menjadi sorotan di mata masyarakat Indonesia, khususnya di tengah pandemi yang masih belum berakhir, yang tidak hanya menghadapi krisis ekonomi, hukum, dan politik, namun juga menghadapi krisis moral yang terjadi pada kalangan remaja dan anak muda lainnya. Pasalnya, potret kekerasan, pembunuhan, dan perilaku yang menyimpang kini mengarah ke dalam seks bebas. Menyikapi berbagai fenomena potret buram dari perilaku remaja yang menyimpang tersebut, sebagaimana cara atau strategi yang harus dilakukan untuk membangun dan memperbaiki generasi bermoral?

Seorang pakar Psikologi, Ikhwan Lutfi, mengatakan bahwa generasi muda kini lebih banyak yang bermasalah dalam etika seperti sopan santun, gaya kerja, cara pandangan mereka, atau semangat idealisme dan hal itu menjadi sebuah fenomena global. Salah satu faktor utama penyebab terjadinya penyimpangan moral pada generasi muda yaitu soal faktor eksternal mereka, seperti media sosial dan tekanan sosial yang mereka alami. Ikhwan Lutfi juga mengatakan "selain faktor eksternal, faktor internal juga terdapat pada instant value yakni segala sesuatu yang hadir secara instan dan cepat, sehingga apapun harus diraih secara instan ini menjadi sebuah masalah, karena dampak yang diberikan pada pengabdian nilai moral itu sendiri”, ungkapnya.

Ia menyampaikan, bahwa moral individu adalah sebuah gambaran ilia dalam kelompok yang akan menjadi gambaran nilai sebuah generasi. Generasi yang bermoral akan melahirkan bangsa dan negara yang baik pula. Maka dari itu, generasi sebelumnya juga ikut bertanggung jawab akan hal tersebut dengan duduk bersama dan membantu semua pihak dan generasi untuk bersama berdiskusi tentang moral.

Sejenak untuk melihat sekitar, menyadari akan fakta-fakta dari krisis moralitas yang tengah terjadi pada kaum remaja, terlebih lagi ketika mengetahui bahwa bangsa ini mengalami bonus demografi, maka bangsa ini sedang berada di tepi jurang kehancuran moralitas dan tinggal menunggu waktu untuk jatuh ke dalamnya. Solusi terbaik untuk memperbaiki karakter bangsa ini adalah dengan melakukan pendidikan karakter kepada para remaja, terutama pendidikan yang dilakukan di keluarga sebagai lembaga pertama dan utama pendidikan anak (Suradika, 2019). Pendidikan karakter bukanlah hal yang asing di telinga kita dalam pendidikan di Indonesia. Bila kita sedikit melihat sejarah bangsa, beberapa para pendidik yang kita tahu 
diantaranya Ki Hajar Dewantara, R.A Kartini, Soekarno, Hatta, Natsir, Tan Malaka dan lainnya yang telah menerapkan semangat dalam pendidikan karakter sebagai pembentuk kepribadian dan identitas sesuai identitas bangsa dengan permasalahan yang terjadi pada saat itu.

FW Foerster mengemukakan bahwa konsep pendidikan karakter yang menekankan dimensi-dimensi etis-spiritual dalam proses pembentukan karakter atau moral dalam pribadi seseorang. Menurutnya pendidikan karakter itu sendiri bertujuan adalah terwujudnya pembentukan karakter dalam kesatuan esensial.

Memahami kompleks dari permasalah krisis moralitas yang dialami oleh para remaja yang sudah dan masih berlangsung terjadi, dan solusi yang tidak dapat secara langsung berhasil namun membutuhkan waktu untuk mewujudkannya. Maka dari itu kita tentu tidak boleh putus asa dalam memperbaiki moralitas para remaja yang tengah mengalami krisis. Jika bangsa ini konsisten dan memiliki tekad yang kuat untuk mengutamakan pendidikan karakter, tentu saja bisa dengan mudah untuk diselesaikan. Syaratnya, pendidikan karakter harus dilakukan secara komprehensifintegral, tidak hanya melalui media pendidikan formal saja, akan tetapi juga dalam pendidikan informal dan non-formal.

Sejatinya pendidikan haruslah mampu mendidik agar terciptanya moral serta akhlak yang baik dan agar tentunya dapat membentuk generasi yang menjunjung tinggi nilai-nilai dan norma kebenaran. Sebagaimana dalam butir isi dari Pancasila alinea kedua yaitu "Kemanusiaan Yang Adil dan Beradab" seharusnya menjadi acuan bagi generasi saat ini untuk mengadopsi nilai Pancasila tersebut. Namun, hal penting dari permasalahan generasi bangsa saat ini adalah sulitnya untuk memahami arti dari pendidikan moral itu sendiri serta adanya factor-faktor yang menjadi pemicu buruk rusaknya moral generasi bangsa.

Untuk mengatasi berbagai masalah mengenai kerusakan moral yang kini tengah terjadi pada para remaja, maka solusi untuk menanggapi masalah tersebut adalah sebagai berikut:

1) Menanamkan pendidikan karakter sejak dini.

2) Pemilihan teman bergaul dan lingkungan yang tepat, karena merekatermasuk kedalam agen sosialisasi sekunder.

3) Mampu memanfaatkan dari perkembangan Ilmu Pengertahuan dan Teknologi (IPTEK) dengan baik dan benar.

4) Memperluas wawasan dan pengetahuan dalam ranah ilmu pengetahuan dan kehidupan sosial.

5) Meningkatkan keimanan dan ketakwaan dalam diri sesusai dengan kepercayaan masing-masing.

6) Mengadakan pendidikan moral dan pengembangan karakter pada suatu mata pelajaran yang diajarkan oleh suatu lembaga pedidikan

7) dll.

\section{KESIMPULAN}

Pada dasarnya permasalahan moralitas yang kini melanda para remaja di tengah pandemi COVID-19 menjadi salah satu masalah yang harus segera untuk diselesaikan. Moralitas yang dimiliki oleh para remaja saat ini bias sudah dibilang sudah kritis dan harus segera diperbaiki. Orang tua dan lembaga pendidikan menjadi salah satu media penting guna memperbaiki krisis moralitas para remaja. Bagai laksana kapal 
tanpa nahkoda di tengah luasnya samudera, terlihat jelas dari maraknya kasus krisis moralitas yang kini melanda para remaja, salah satunya adalah tawuran antar pelajar. Kemudian sebuah kebohongan yang secara jelas terbuka telah menjadi hal yang maklum dalam keseharian kita. Pentingnya penanaman pendidikan karakter atau moral kepada remaja saat ini memang diperlukan. Seperti mulai membiasakan mengucapkan kata "tolong" ketika membutuhkan sebuah bantuan, kemudian mengucapkan kata "terima kasih" ketika sudah ditolong oleh orang lain, dan mengucapkan kata "maaf" ketika melakukan sebuah kesalahan. Akan tetapi semua hal tersebut sudah jarang ditemukan di lingkungan remaja saat ini. Alih-alih perkembangan zaman, justru melunturkan karakter atau moral dalam diri remaja. Seperti tidak mengucapkan tolong ketika membutuhkan bantuan, kemudian tidak mengucapkan terima kasih ketika sudah ditolong oleh orang lain, dan mengganti kata maaf dengan kata "baper". Perkembangan zaman memang tidak bisa dihindari oleh kita sebagai manusia. Tetapi itu semua tergantung dari diri kita masing-masing bagaimana menyikapi sebuah perkembangan zaman yang kita alami. Istilah kata "baper" juga merupakan pengaruh dari perkembangan zaman dalam dunia bahasa. Banyak sekali kasus yang terjadi pada remaja jika mereka mengungkapkan sebuah bahasa yang mungkin bisa membuat ketersinggungan terhadap lawan bicaranya, alih-alih bukan mengucapkan "maaf" tetapi mereka malah mengucapkan kata "baper" dan lupa akan maksa dari kata tersebut. Tentu hal tersebut termasuk dalam salah satu krisis moralitas. Keluarga sebagai agen sosial primer dalam membimbing anaknya untuk membentuk karakter yang baik dan lingkungan pergaulan serta lingkungan pendidikan yang menjadi agen sosial sekunder dalam pembentukan karakter. Kedua agen sosial mau itu primer atau sekunder akan sangat berpengaruh ketika tidak ada keseimbangan antara keduanya, sehingga hal tersebut yang membuat perilaku para remaja menjadi menyimpang dan tanpa disadari ia sudah mengalami krisis moralitas dalam dirinya. Dengan mengarahkan karakter atau moral para remaja, dapat memperbaiki krisis moralitas yang kini tengah berada di tengah pandemi ini. Komunikasi dua arah antara pelaku krisis moral dengan orang yang ingin membantu untuk memperbaiki kerusakan moral dalam diri pelaku bisa dibilang cukup efektif. Walaupun membutuhkan waktu yang cukup lama, akan tetapi hal tersebut dapat menjadi efektif apabila komunikasi dua arah tersebut terus menerus dilakukan. Kemudian melakukan literasi dalam perkembangan zaman dan budaya luar yang masuk kepada para remaja. Kemudian kekompakan antara keluarga sebagai agen sosial primer dan lingkungan pergaulan dan lingkungan pendidikan sebagai agen sosial sekunder akan memperbaiki krisis moralitas dalam diri remaja tersebut, dan kita bersama-sama membantu para remaja untuk memperbaiki moralitasnya agar menjadi generasi penerus bangsa yang bermanfaat.

\section{REFERENSI}

Hurlock, E. B. (2011). Psikologi Perkembangan: Suatu Pendekatan Sepanjang Rentang Kehidupan Edisi Kelima. Jakarta: Erlangga, Edisi 5, 205-243. 


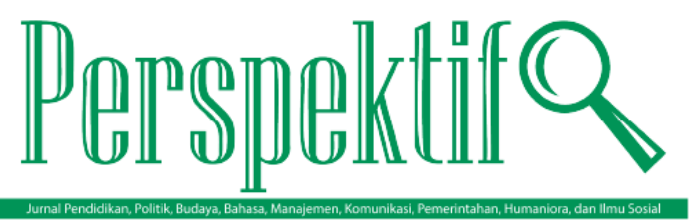

Kemdikbud. (2020). Surat Edaran Mendikbud No 4 Tahun 2020 Tentang Pelaksanaan Kebijakan Pendidikan Dalam Masa Darurat Penyebaran Corona Virus Disease (Covid- 19) Pusdiklat Pegawai Kementerian Pendidikan Dan Kebudayaan. In Https://pusdiklat.kemdikbud.go.id/.

Menteri Pendidikan dan Kebudayaan Republik Indonesia.

Koyan, I. W. (2000). Pendidikan moral pendekatan lintas budaya. Depdiknas.

Lickona, T., \& Wamaungo, J. A. (2013). Educating for Character: How Our Schools Can Teach Respect and Responsibility Mendidik untuk Membentuk Karakter Bagaimana Sekolah Dapat Memberikan Pendidikan tentang Sikap Hormatt dan Bertanggung Jawab (J. A. Wamaungo \& U. Wahyudin (eds.)). Bumi Aksara.

Nurohmah, A. N., \& Dewi, D. A. (2021). Penanaman Nilai Moral dan Karakter di Era Pandemi melalui Pendidikan dengan Mengimplementasikan NilaiNilai Pancasila. Journal of Education, Psychology and Counseling, 3(1), 119-128.

Purwandari, G., Winata, W., \& Suradika, A. (2021). Pemberdayaan pendidikan melalui kegiatan pojok membaca di Rawakalong. Prosiding Seminar Nasional ..., 1(1), 1-7.

Santoso, S. A., \& Chotibuddin, M. (2020). PEMBELAJARAN BLENDED LEARNING MASA PANDEMI. Penerbit Qiara Media. Qiara Media.

Suradika, Agus. 2019. Pendidikan Keluarga dan Keluarga Berpendidikan: Perspektif Islam. Jakarta: Direktorat Advokasi dan KIE BKKBN.

Tilaar, H. A. R. (1998). Beberapa agenda reformasi pendidikan nasional dalam perspektif abad 21. Tera Indonesia. 